\title{
Influence of Gender on Circulating Cardiac Natriuretic Hormones in Patients with Heart Failure
}

\author{
Michele Emdin1, Claudio Passino', Silvia Del Ry', \\ Concetta Prontera ${ }^{1}$, Fabio Galetta ${ }^{2}$ and Aldo Clerico ${ }^{1 *}$ \\ 1 Department of Cardiovascular Endocrinology, CNR Institute \\ of Clinical Physiology, \\ 2 Department of Internal Medicine, \\ University of Pisa, Pisa, Italy
}

In order to study the influence of gender on circulating levels of cardiac natriuretic hormones (CNHs) in heart failure, we measured the plasma levels of atrial natriuretic peptide (ANP) and brain natriuretic peptide (BNP) by means of highly sensitive and specific IRMA methods in 239 consecutive patients (age $64.7 \pm 11.6$ years, range 21-89 years; 170 men and 69 women) with cardiomyopathy. There was different response of $\mathrm{CNH}$ according to gender in patients with heart failure, as indicated by the ratio between the individual $\mathrm{CNH}$ values of patients and the gender-specific cut-off values. Indeed, the mean ratio for ANP found in men $(3.6 \pm 3.6)$ was significantly higher $(p=0.0075)$ than that found in women $(2.4 \pm 2.1)$. The mean ratio for BNP was on average 2.3 fold higher $(15.9 \pm 27.1$ in men and $6.9 \pm 6.8$ in women, $p=0.0084$ ). Moreover, age, ejection fraction, and disease severity independently and significantly contributed to regression with both ANP $(R=0.612$, $F=39.969, p<0.0001)$ and $B N P(R=0.656, F=49.957$, $p<0.0001$ ) values, while gender did not. In conclusion, our study suggests a different, gender-specific activation of the CNH system in this clinical condition, although age, ejection fraction and disease severity seem to be more powerful predictors than gender of circulating levels of ANP and BNP in patients with heart failure. Clin Chem Lab Med 2003; 41(5):686-692

Key words: ANP; BNP; Cardiac hormones; Gender; Heart failure.

Abbreviations: ANP, atrial natriuretic peptide; BNP, brain natriuretic peptide; $\mathrm{CNH}$, cardiac natriuretic hormone; CNP, C-type natriuretic peptide; $E F$, ejection fraction; IRMA, immunoradiometric assay; RIA, radioimmunoassay.

\section{Introduction}

Human cardiomyocytes secrete a family of related peptide hormones (cardiac natriuretic hormones; CNHs) with powerful diuretic, natriuretic, and vascular smooth muscle-relaxing effects, as well as complex interactions with other neurohormonal systems, as recently

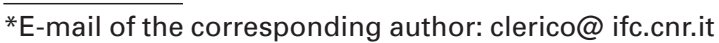

reviewed (1-6). CNHs include atrial natriuretic peptide (ANP), brain natriuretic peptide (BNP), and their related peptides (including proANP- and proBNP-related peptide); while C-type natriuretic peptide(CNP) and urodilatin, structurally related to the ANP/BNP family, are not secreted by the heart but by other tissues (1-6).

$\mathrm{CNH}$ are greatly increased in diseases characterized by an expanded fluid volume (2). In particular, the importance of measuring circulating levels of these peptide hormones for the classification of patients with heart failure and/or for predicting their mortality/survival rates, has been recently reported (1-7).

Age and sex are two well-recognized cardiovascular risk factors (8). The incidence of ischemic heart disease increases with age, however, it is lower in women during their child-bearing years than in men, while after menopause this difference disappears (8-14).

The relationship between $\mathrm{CNHs}$ and gender and/or age has been little investigated in humans, both in healthy subjects $(2,15-22)$ and in patients with heart failure (23). This lack of studies specifically dedicated to the influence of age and gender on the $\mathrm{CNH}$ system could be due to methodological problems, i.e., difficulty with finding a sufficient number of truly healthy subjects over 65 years of age, since approximately $85 \%$ of the people over the age of 65 suffer from one or more chronic conditions (24). Another methodological problem is related to the very low plasma concentrations of $\mathrm{CNH}$ s in normal adults (on average about $10-20 \mathrm{pg} / \mathrm{ml}$ ), which often are below, or close to, the sensitivity level of immunoassay methods generally used to measure these hormones $(2,25)$. On the whole, the reference values for ANP and BNP, commonly used in pathophysiological studies as well as in clinical practice, have been calculated from a small number of subjects, without taking into account possible effects of age and sex. This is important because it is well known that the incidence of cardiac disease increases progressively with age $(14,15,24)$.

On the other hand, there is growing evidence for potential gender differences in subjects with heart failure: several studies addressed diagnosis, epidemiology, response to treatment, and outcome of this disease (23, 26-33). Taken as a whole, these studies suggest a lower susceptibility of middle-aged women to heart failure, a more favorable clinical course of disease in this group, and even better survival (23).

To explain, at least in part, these findings, it has been suggested that female sex steroid hormones have a cardioprotective role in normal cycling women and in postmenopausal women treated with hormone replacement therapy (9-13). Recent studies from our laboratory suggest that, if there is a cardioprotective ac- 
tion of sex steroid hormones, this could be, at least in part, mediated by the CNHs $(22,34)$.

In order to study the influence of gender on circulating levels of $\mathrm{CNHs}$ and its possible pathophysiological role in heart failure, we measured the plasma levels of ANP and BNP by means of highly sensitive and specific IRMA methods $(17,19,35)$ in two large groups of healthy adult subjects and in patients with different severity of heart failure.

\section{Subjects, Materials and Methods}

\section{Control group}

The control group consisted of 222 healthy subjects (109 men and 113 women) with age ranging from 20 to 77 years (mean age $43.9 \pm 14.6$ years). Physiological characteristics of this population were reported in detail elsewhere (22). In particular, women did not take female steroid hormones (i.e., contraceptive steroids or hormone replacement therapy) and all the subjects had normal thyroid function. Moreover, we present here only the ANP and BNP data, which are of interest for the present study. The mean ANP value found was $17.8 \pm 10.9 \mathrm{pg} / \mathrm{ml}$ $(16.7 \pm 10.0 \mathrm{pg} / \mathrm{ml}$ in men and $18.8 \pm 11.7 \mathrm{pg} / \mathrm{ml}$ in women). The 97.5th percentile for ANP values (considered as cut-off) of for the whole population was $42 \mathrm{pg} / \mathrm{ml}(39 \mathrm{pg} / \mathrm{ml}$ for men and $49 \mathrm{pg} / \mathrm{ml}$ for women). The mean BNP value was $9.9 \pm 8.9 \mathrm{pg} / \mathrm{ml}$ $(7.7 \pm 7.0 \mathrm{pg} / \mathrm{ml}$ in men and $12.3 \pm 10.0 \mathrm{pg} / \mathrm{ml}$ in women, $\mathrm{p}<0.0001$, respectively). The 97.5 th percentile for the distribution of BNP values for the whole population was $39 \mathrm{pg} / \mathrm{ml}$ (24 pg/ml for men and $39 \mathrm{pg} / \mathrm{ml}$ for women).

\section{Patients with heart failure}

We studied 239 consecutive patients (age $64.7 \pm 11.6$ years, range $21-89$ years; 170 men and 69 women) with chronic cardiomyopathy, admitted to our Institute. Male patients had a mean age $(63.5 \pm 11.9$ years $)$, significantly lower than that of female patients $(68.0 \pm 10.0$ years, $p=0.0096)$. Cardiac morphology and function were assessed by 2D-echocardiography, radionuclide ventriculography, or cardiac catheterization, as appropriate. In order to study patients with a significant reduction of left ventricular function, only patients with ejection fraction less than $45 \%$ were enrolled in the study.

The patients were divided into two subsets according to the New York Heart Association (NYHA) functional class: $52 \%$ of the patients were in I-II NYHA class and $48 \%$ in III-IV NYHA class.

Patients were treated with a relative restriction of watersodium intake (using a personalized diet with a sodium intake of 100-140 mmol/day) and with optimal pharmacological treatment including digitalis, vasodilators (generally angiotensin converting enzyme (ACE) inhibitors, nitrates), diuretics (frusemide and/or potassium-sparing agents), and/or carvedilol. Moreover, women did not take female steroid hormones (i.e., contraceptive steroids or hormone replacement therapy) and all the patients had normal thyroid function.

Moreover, patients with atrial fibrillation, as well as those with an acute myocardial infarction or myocarditis, which may affect the secretion and/or metabolism of $\mathrm{CNHs}$, were also excluded from the study.

Informed consent was obtained from all individuals enrolled in the study.

\section{Plasma samples}

We collected blood samples between 8 am and 9 am after an overnight fast, and after $15 \mathrm{~min}$ of rest in a supine position. Af- ter collection, blood samples $(10 \mathrm{ml})$ were immediately put into ice-chilled disposable polypropylene tubes containing aprotinin $(500 \mathrm{KIU} / \mathrm{ml}$ of plasma) and EDTA $(1 \mathrm{mg} / \mathrm{ml}$ of plasma). Plasma samples were rapidly separated by centrifugation for $15 \mathrm{~min}$ at $4{ }^{\circ} \mathrm{C}$, and then frozen and stored until assay (usually performed within one month) at $-20^{\circ} \mathrm{C}$ in $1 \mathrm{ml}$ aliquots in polypropylene tubes.

\section{ANP and BNP IRMAs}

Plasma ANP and BNP were measured (at least in duplicate) with two-site (sandwich) IRMA methods, previously set up in our laboratory, which do not require a preliminary step for extraction or purification of plasma samples (direct assay) (17, $19,35)$. These IRMA methods use two monoclonal antibodies prepared against two sterically remote epitopes of the human ANP or BNP molecule, of which one is included in the ring structure of the peptide chain. One antibody is coated onto the solid phase beads and the other is radiolabeled with ${ }^{125}$.

The assay sensitivity of ANP IRMA was about $2 \mathrm{pg} / \mathrm{ml}$ and the working range was from 10 to $2000 \mathrm{pg} / \mathrm{ml}(17,35)$. The between-assay precision (CV\%) was $11.4 \%$ (mean $\pm \mathrm{SD}=$ $22.6 \pm 2.6 \mathrm{pg} / \mathrm{ml}, \mathrm{n}=16)$ and $10.7 \%(25.6 \pm 2.7 \mathrm{pg} / \mathrm{ml}, \mathrm{n}=12)$ for the two plasma pools with ANP concentrations in the normal range, prepared by pooling together several plasma samples collected from normal subjects, and $8.0 \%(178.6 \pm 14.3 \mathrm{pg} / \mathrm{ml}$, $\mathrm{n}=16)$ and $6.7 \%(162.2 \pm 10.8 \mathrm{pg} / \mathrm{ml}, \mathrm{n}=12)$ for the other two pools with ANP levels above the normal range, prepared by pooling several plasma samples collected from patients with heart failure.

The assay sensitivity of BNP IRMA was about $2.5 \mathrm{pg} / \mathrm{ml}$ and the working range was from 5 to $2000 \mathrm{pg} / \mathrm{ml}(17,19)$. The between-assays precision was $11.0 \%$ for one plasma pool with BNP concentration in the normal range $(5.10 \pm 0.56 \mathrm{pg} / \mathrm{ml}, \mathrm{n}=$ $10)$, prepared by pooling together several plasma samples collected from normal subjects, and $9.0 \%(58.7 \pm 5.3 \mathrm{pg} / \mathrm{ml}, \mathrm{n}=$ 10) for another pool with BNP concentration above the upper limit of normal range, prepared by pooling several plasma samples collected from patients with heart failure.

\section{Statistical analysis}

Statistical analysis was carried out on a Power Macintosh G3 personal computer using the Stat-View 5.0.1 program (1992-98, SAS Institute Inc., SAS Campus Drive, Cary, NC, USA). Because ANP and BNP values in healthy subjects are not normally distributed, the logarithmic transformation of data were used for statistical analysis. ANP or BNP values, considered as dependent variables, and gender, ejection fraction values, and the severity of disease, considered as independent variables, were also analyzed by linear multiple regression analysis using a stepwise model (forward selection) and the logarithmic transformation of original data. In this type of analysis, the severity of disease was considered to be a dummy variable, assigning score 1 to mild disease (NYHA class I-II) and score 3 to severe disease (NYHA class III-IV), while gender was another dummy variable with score 0 for women and score 1 for men.

The results are expressed as mean \pm SD if not otherwise stated. $\mathrm{p}$-Values were considered significant when less than 0.05 .

\section{Results}

As expected, greatly increased $\mathrm{CNH}$ s were found in patients with heart failure compared to healthy subjects 
$(p<0.0001)$. The mean ANP value found in patients with heart failure of both sexes was $132.8 \pm 131.0 \mathrm{pg} / \mathrm{ml}$ (median $=87.5$, range $5.3-922.0 \mathrm{pg} / \mathrm{ml}$ ), while the mean BNP value in the same patients was $342.9 \pm 568.4 \mathrm{pg} / \mathrm{ml}$ (median $193.8 \mathrm{pg} / \mathrm{ml}$, range of $3.7-7018.0 \mathrm{pg} / \mathrm{ml}$ ). The ANP and BNP values observed, categorized according to gender and severity of heart failure, are reported in Table 1; as also expected, higher values of $\mathrm{CNHs}$ were found in patients with more severe disease. Moreover, there were no significant differences between the $\mathrm{CNH}$ values found in men and women.

In order to better estimate whether there is a different response of the $\mathrm{CNH}$ system according to gender in patients with heart failure, we calculated the ratio between the respective $\mathrm{CNH}$ values of patients and the different cut-off values for ANP (i.e., $39 \mathrm{pg} / \mathrm{ml}$ for men and $49 \mathrm{pg} / \mathrm{ml}$ for women) or BNP (i.e., $24 \mathrm{pg} / \mathrm{ml}$ for men and $39 \mathrm{pg} / \mathrm{ml}$ for women). For ANP, the mean ratio found in men $(3.6 \pm 3.6)$ was significantly higher $(p=$

Table 1 ANP and BNP values of patients with heart failure classified according to gender and degree of heart failure. Mild disease includes patients in NYHA functional classes I and II, while severe disease indicates patients in NYHA functional classes III and IV.

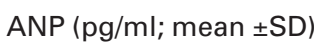

\begin{tabular}{llll}
\hline $\begin{array}{l}\text { Severity of heart } \\
\text { failure }\end{array}$ & Men & Women & $\mathrm{p}^{*}$ \\
\hline $\begin{array}{l}\text { Combined mild } \\
\text { and severe }\end{array}$ & $\begin{array}{l}141.2 \pm 140.7 \\
(166)\end{array}$ & $\begin{array}{l}114.9 \pm 101.3 \\
(68)\end{array}$ & 0.2606 \\
Mild & $\begin{array}{l}94.4 \pm 105.3 \\
(80)\end{array}$ & $\begin{array}{l}64.5 \pm 56.0 \\
(40)\end{array}$ & 0.2681 \\
& $195.3 \pm 157.6$ & $217.5 \pm 97.9$ & 0.0827 \\
Severe & $(86)$ & $(28)$ & \\
& $<0.0001$ & $<0.0001$ & \\
$\mathrm{p}^{* *}$ & & & \\
\hline
\end{tabular}

$\mathrm{BNP}(\mathrm{pg} / \mathrm{ml}$; mean \pm SD)

\begin{tabular}{llll}
\hline $\begin{array}{l}\text { Severity of heart } \\
\text { failure }\end{array}$ & Men & Women & $\mathrm{p}^{*}$ \\
\hline $\begin{array}{l}\text { Combined mild } \\
\text { and severe }\end{array}$ & $\begin{array}{l}381.9 \pm 649.6 \\
(165)\end{array}$ & $\begin{array}{l}252.0 \pm 266.8 \\
(68)\end{array}$ & 0.1577 \\
Mild & $\begin{array}{l}177.0 \pm 203.9 \\
(79)\end{array}$ & $\begin{array}{l}112.2 \pm 121.9 \\
(40)\end{array}$ & 0.1726 \\
& $604.2 \pm 863.4$ & $\begin{array}{l}510.4 \pm 281.1 \\
(28)\end{array}$ & 0.5310 \\
Severe & $(86)$ & & \\
$\mathrm{p}^{* *}$ & $<0.0001$ & $<0.0001$ & \\
\hline
\end{tabular}

* p-Values between gender groups calculated by means of the $t$ test for unpaired data using the logarithmic transformation of original data set; **p-values calculated between patients with mild and severe disease by means of the test for unpaired data using the logarithmic transformation of original set of concentration values. The numbers of patients studied are indicated within parentheses.
$0.0075)$ than that found in women $(2.4 \pm 2.1)$. In particular, this ratio was $2.4 \pm 2.7$ and $1.4 \pm 1.2(p=0.0298)$ in male and female patients with mild disease, while it was $5.0 \pm 4.0$ and $4.4 \pm 2.0$ in male and female patients with more severe disease $(p=0.5240)$, respectively (Figure 1). For BNP, the mean ratio found in men $(15.8 \pm 27.1)$ was significantly higher $(p=0.0084)$, on av-

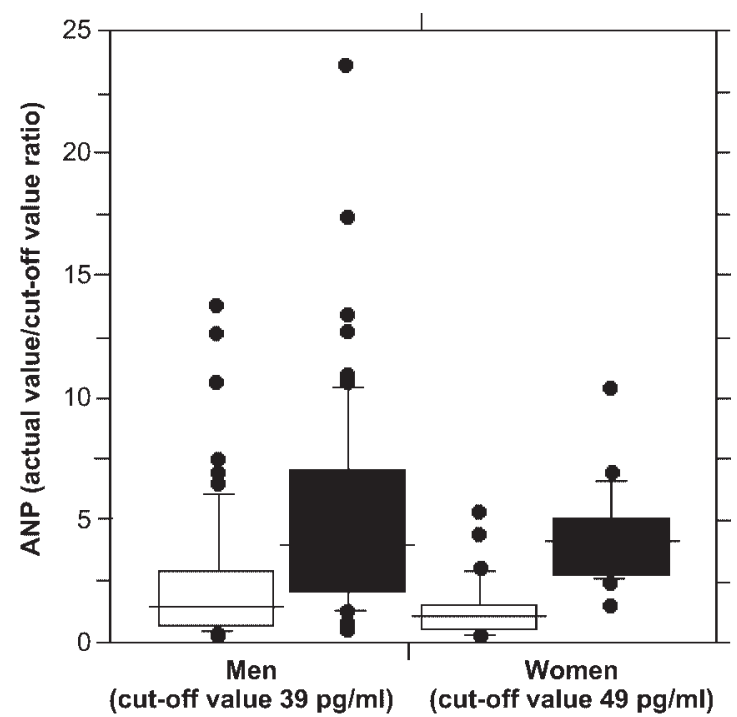

Figure 1 Ratios between the individual ANP values of patients and the different cut-off values in men (39 pg/ml) and in women $(49 \mathrm{pg} / \mathrm{ml})$. The results are expressed as boxes with five horizontal lines, displaying the 10th, 25th, 50th (median), 75th, and 90th percentiles. All values above the 90th percentile and below the 10th percentile (outliers) are plotted separately (as circles). Mild disease $\square$; Severe disease

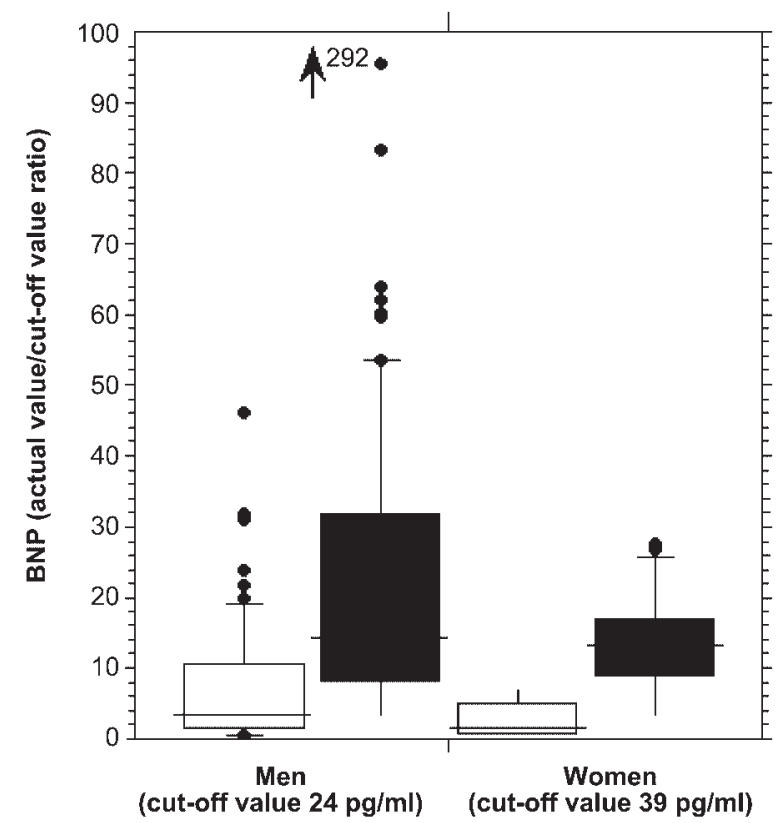

Figure 2 Ratios between the indiviual BNP values of patients and the different cut-off values found in men $(24 \mathrm{pg} / \mathrm{ml})$ and in women $(39 \mathrm{pg} / \mathrm{ml})$. The results are expressed as boxes with five horizontal lines, displaying the 10th, 25th, 50th (median), 75th, and 90th percentiles. All values above the 90th percentile and below the 10th percentile (outliers) are plotted separately (as circles). Mild disease $\square$; Severe disease 
erage 2.3 times, than that found in women $(6.9 \pm 6.8)$. This ratio was $7.1 \pm 8.3$ and $3.5 \pm 3.8(p=0.0157)$ in male and female patients with mild disease, while it was $25.1 \pm 35.8$ and $13.2 \pm 7.3$ in male and female patients with more severe disease $(p=0.1225)$, respectively (Figure 2).

As expected, negative linear regressions were found between the logarithmically transformed ANP (Figure 3) and BNP (Figure 4) values and the left ventricular ejection fraction (EF) of patients with heart failure. However, gender did not affect EF in patients with the same severity of disease, as reported in Table 2. We used the analysis of covariance (ANCOVA) to test the influence of gender (considered as effect factor) on the relationship between $\mathrm{CNH}$ levels (considered as dependent variable) and the EF values (considered as covariate variable). These data suggest that gender does not significantly affect the inter-relationships between the individual ANP (Table 3) or BNP (Table 4) levels and the respective EF values in patients with heart failure.

In order to consider the possible effect of age, gender, EF, and disease severity as determinants of circulating levels of $\mathrm{CNHs}$, we analyzed the data from all patients with heart failure by multiple stepwise regression analysis, where ANP or BNP values were consid-

A) Male patients

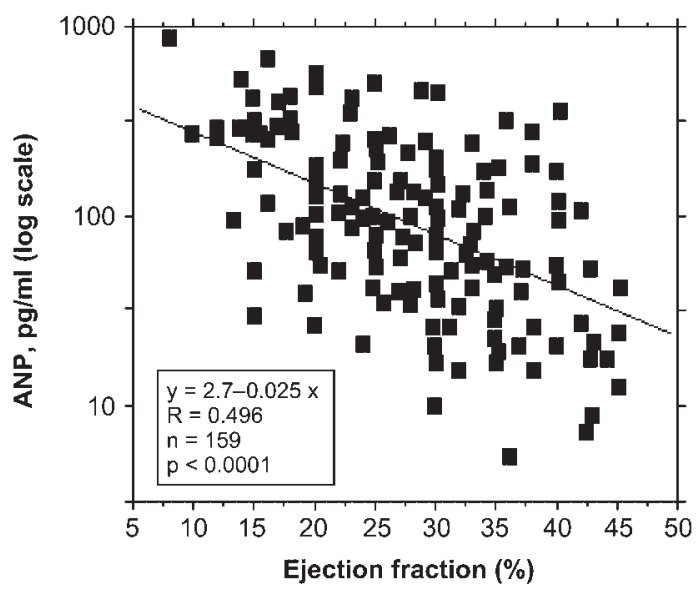

B) Female patients

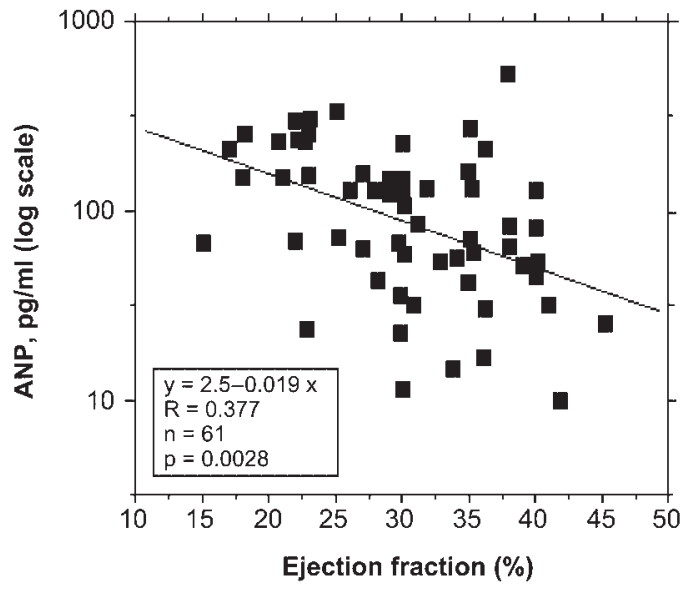

Figure 3 Linear regression analysis of the relationship between plasma ANP (logarithmic transformation) and ejection fraction $(E F)$ in men $(A)$ and women $(B)$. ered dependent variables, and gender, age, EF, and severity of disease were independent variables. Age, $E F$, and disease severity independently and signifi-

Table 2 Ejection fraction values (\%) in patients with heart failure classified according to the severity of the disease and gender.

\begin{tabular}{llll}
\hline $\begin{array}{l}\text { Severity of heart } \\
\text { failure }\end{array}$ & $\begin{array}{l}\text { Men } \\
\mathrm{EF}(\%) \\
\text { (Mean } \pm \mathrm{SD})\end{array}$ & $\begin{array}{l}\text { Women } \\
\text { (EF\%) } \\
\text { (Mean } \pm \mathrm{SD} \text { ) }\end{array}$ & $\mathrm{p}^{*}$ \\
\hline $\begin{array}{l}\text { Combined mild } \\
\text { and severe }\end{array}$ & $\begin{array}{l}28.4 \pm 8.8 \\
(159)\end{array}$ & $\begin{array}{l}30.9 \pm 7.6 \\
(62)\end{array}$ & 0.0497 \\
Mild & $31.9 \pm 8.6$ & $\begin{array}{l}33.5 \pm 6.3 \\
(37)\end{array}$ & 0.3490 \\
& $(76)$ & $26.3 \pm 7.7$ & 0.4812 \\
Severe & $24.9 \pm 8.1$ & $(25)$ & \\
& $(83)$ & 0.0004 & \\
$\mathrm{p}^{* *}$ & $<0.0001$ & &
\end{tabular}

*p-Values calculated for the EF values found in men and women by means of the $t$ test for unpaired data; ${ }^{*}$ p-values calculated for patients with mild and severe disease by means of the $t$ test for unpaired data. The numbers of patients studied are indicated within parentheses.

A) Male patients

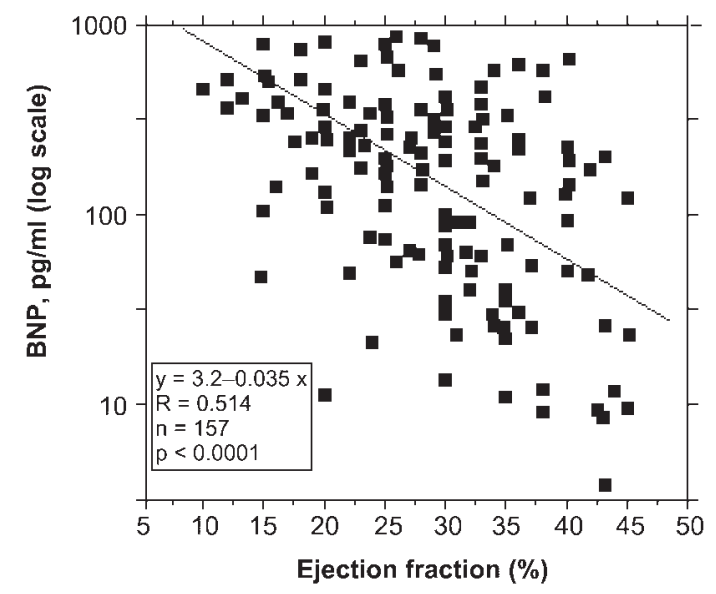

B) Female patients

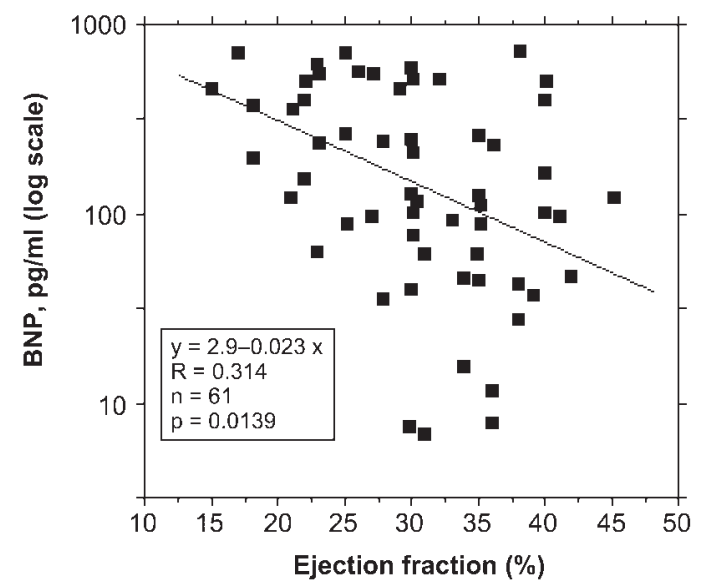

Figure 4 Linear regression analysis of the relationship between plasma BNP (logarithmic transformation) and ejection fraction $(E F)$ values in men $(A)$ and women $(B)$. 
Table 3 ANCOVA analysis of ANP values (logarithmic transformation) of patients with heart failure.

\begin{tabular}{lrrr}
\hline & DF & F-value & p-value \\
\hline Gender & 1 & 0.269 & 0.6046 \\
EF & 1 & 36.695 & $<0.0001$ \\
Gender * EF & 1 & 0.536 & 0.4648 \\
Residual & 216 & & \\
\hline
\end{tabular}

Table 4 ANCOVA analysis of BNP values (logarithmic transformation) of patients with heart failure.

\begin{tabular}{lrrr}
\hline & DF & F-value & p-value \\
\hline Gender & 1 & 1.284 & 0.2585 \\
EF & 1 & 34.020 & $<0.0001$ \\
Gender * EF & 1 & 1.464 & 0.2276 \\
Residual & 214 & &
\end{tabular}

Gender * EF: interaction term between gender and EF, DF: degree of freedom.

cantly contributed to the regression with logarithmic transformation of original data both for ANP $(R=0.612$, $\mathrm{F}=39.969, \mathrm{p}<0.0001)$ and $\mathrm{BNP}(\mathrm{R}=0.656, \mathrm{~F}=49.957$, $\mathrm{p}<0.0001$ ), while gender did not.

\section{Discussion}

An independent stimulatory effect of aging and female sex hormones on ANP and BNP levels in healthy adult subjects has been recently suggested (22). Women showed higher levels of plasma BNP than men throughout adult life (20 to 80 years of age), while ANP values were higher in women only until the menopause (22). These data suggest that production/secretion, turnover and/or peripheral sensitivity of $\mathrm{CNH}$ s are differently regulated in men and women throughout the adult life.

Several studies have suggested a cardioprotective role for endogenous sex female steroid hormones in normal cycling women and for estrogen replacement therapy in postmenopausal women (9-13). Two recent studies from our laboratory indicated that this cardioprotective action could be mediated, at least in part, by the stimulatory effect of estrogens on the $\mathrm{CNH}$ system $(22,34)$. This cardioprotective action may explain the lower incidence of cardiovascular disease in normal cycling women compared to men of the same age, as well as the gender-specific differences in the pathophysiological and biochemical mechanisms of heart failure $(14,23,24,36,37)$.

Very recently, Luchner et al. (23) suggested a genderspecific control of myocardial adaptation to hemodynamic overload and a more rapid induction of left ventricular hypertrophy during myocardial dysfunction in men than in women. In this population-based study, men with moderate or severe left ventricular dysfunction were characterized by an increase in $\mathrm{CNH}$ levels; in contrast, $\mathrm{CNH}$ levels increased to a lesser extent and only in women with severe left ventricular dysfunction (23). However, a limitation of this study is that, even if 1883 subjects were enrolled into the study, only $2.5 \%$ (23 men and 25 women) showed left ventricular dysfunction according to the clinical and experimental protocol used. Furthermore, the measurements of ANP and BNP were performed only in some of these subjects (23). Finally, left ventricular dysfunction was significantly greater in males, obviously influencing $\mathrm{CNH}$ levels (EF: $37 \pm 2$ vs. $43 \pm 1 \%$ ). Our data also suggest that there is a different, gender-related response of the $\mathrm{CNH}$ system between male and female patients with heart failure.

Indeed, plasma ANP and BNP levels are not significantly different between male and female patients, even if, on average, male patients have higher levels than female patients (Table 1). However, it is is important to note that male patients are on average significantly younger than female patients $(63.5$ vs. 68.0 years). The effect of lower age of males tends to reduce the difference in $\mathrm{CNH}$ levels between genders, because $\mathrm{CNH}$ levels increase with aging in both sexes, and healthy women aged over 50 years generally show higher $\mathrm{CNH}$ levels (especially for BNP) than men of the same age (22).

Due to the higher circulating $\mathrm{CNH}$ values in women than in men, gender-specific cut-off values (such as the 97.5th percentile of ANP or BNP distribution values) have been recently recommended in clinical practice $(22,38,39)$.

In particular, the use of gender-specific cut-off values for ANP and BNP can allow the calculation of an index of hormonal response as the ratio between the hormone levels of patients with heart failure and the respective, gender-related, cut-off values. Since the cutoff values are greater for women than for men, while the mean $\mathrm{CNH}$ concentrations are not significantly different between male and female patients (Table 1), this ratio became smaller for women than for men.

Therefore, our study suggests that male patients show a greater activation of the $\mathrm{CNH}$ system than female patients (Figure 1 and 2). In particular for BNP, this index indicates that male patients with heart failure show, on average, an increase in hormone levels of approximately 20 times compared to healthy men, while female patients show an increase in hormone levels of approximately 7 times compared to healthy women.

Furthermore, our data suggest that male patients with heart failure have a greater and earlier activation of the $\mathrm{CNH}$ system than female patients (expecially for BNP). However, with the progression of the disease from mild to severe, the degree of hormone activation tends to reach a maximum with similar circulating levels in male and female patients for both ANP and BNP.

Since there is a close negative relationship between EF and circulating levels of CNH (Figure 3 and 4), it could be hypothesized that the gender-related difference in hormone response may be due to lower EF values of male patients with heart failure than those of female patients. However, the data reported in Table 2 indicate that there were no significant differences in EF 
values between male and female patients, when considering the severity of disease. Furthermore, gender does not significantly affect the relationships between the individual ANP (Table 3) or BNP (Table 4) levels and the respective $E F$ values of patients with heart failure.

Finally, age, EF, and severity of disease, but not gender, were found to be independently related to circulating levels of ANP and BNP by multiple regression analysis; this indicates that hemodynamics and/or other pathophysiological mechanisms are more powerful predictors of activation of the $\mathrm{CNH}$ system than gender in patients with heart failure.

In conclusion, our study suggests a gender-specific activation of the $\mathrm{CNH}$ system in this clinical condition, though age, ejection fraction, and disease severity seem to be more powerful predictors of circulating levels of ANP and BNP than gender in patients with heart failure.

\section{References}

1. Sagnella GA. Measurement and significance of circulating natriuretic peptides in cardiovascular diseases. Clin Sci 1998; 95:519-29.

2. Clerico A, lervasi G, Mariani G. Clinical relevance of the measurement of cardiac natriuretic peptide hormones in humans. Horm Metab Res 1999; 31:487-98.

3. Boomsma F, Van den Meiracker AH. Plasma A- and B-type natriuretic peptides: physiology, methodology and clinical use. Cardiovasc Res 2001; 51:442-9.

4. Suzuki T, Yamazaki T, Yazaki Y. The role of the natriuretic peptides in the cardiovascular system. Cardiovasc Res 2001; 51:489-94.

5. Mair J, Hammerer-Lercher A, Puchendorf B. The impact of cardiac natriuretic peptide determination on the diagnosis and management of heart failure. Clin Chem Lab Med 2001; 39:571-88.

6. Maisel A. B-type natriuretic peptide levels: a potential novel "white count" for congestive heart failure. J Cardiac Failure 2001; 7:183-93.

7. Struthers AD. Introducing a new role for BNP: as a general indicator of cardiac structural disease rather than a specific indicator of systolic dysfunction only. Heart 2002; 87: 97-8.

8. Maron DJ, Ridker PM, Pearson TA, Grundy SM. Dyslipidemia, other risk factors, and the prevention of coronary heart disease. In: Fuster V, Alexander RW, O'Rourke RA, Roberts R, King SB, Wellens HJJ, editors. Hurst's - the heart, 10th ed. New York: McGraw Hill Companies Inc, 2001:1131-60.

9. Kuroski de Bold ML. Estrogen, natriuretic peptides and the renin-angiotensin system. Cardiovasc Res 1999; 41:52431.

10. Rosano GMC, Chierchia SL, Leonardo F, Beale CM, Collins P. Cardioprotective effects of ovarian hormones. Eur Heart J 1996; 17(Suppl D):15-9.

11. Sotelo MM, Johnson RS. The effects of hormone replacement therapy on coronary heart disease. Endocrinol Metab Clin North Am 1997; 26:313-28.

12. Johnson SR. Menopause and hormone replacement therapy. Med Clin North Am 1998; 82: 297-20.

13. Clinical Synthesis Panel on HRT. Hormone replacement therapy. Lancet 1999; 354:152-5.

14. Lakatta EG, Boluyt MO. Age-associated changes in the cardiovascular system in the absence of cardiovascular dis- ease. In: Hosenpud JD, Greenberg BH, editors. Congestive heart failure, 2nd ed. Philadelphia: Lippincott Willians \& Wilkins, 2000:137-56.

15. Clark BA, Elahi D, Epstein FH. The influence of gender, age, and the menstrual cycle on plasma atrial natriuretic peptide. J Clin Endocrinol Metab 1990; 70:349-52.

16. Maffei S, Clerico A, lervasi G, Nannipieri M, Del Ry S, Giannessi $D$, et al. Circulating levels of cardiac natriuretic hormones measured in women during menstrual cycle. $J$ Endocrinol Invest 1999; 22:1-5.

17. Clerico A, lervasi G, Del Chicca MG, Emdin M, Maffei S, Nannipieri $M$, et al. Circulating levels of cardiac natriuretic peptides (ANP and BNP) measured by highly sensitive and specific immunoradiometric assays in normal subjects and in patients with different degrees of heart failure. J Endocrinol Invest 1998; 21:170-9.

18. Jensen KT, Carstens J, Ivarsen P, Pedersen EB. A new, fast, and reliable radioimmunoassay of brain natriuretic peptide in human plasma; reference values in healthy subjects and in patients with different diseases. Scand J Clin Lab Invest 1997; 57:529-40.

19. Del Ry S, Clerico A, Giannessi D, Andreassi MG, Caprioli R, lascone MR, et al. Measurement of brain natriuretic peptide in plasma samples and cardiac tissue extracts by means of an IRMA method. Scand J Clin Lab Invest 2000; 60:81-90.

20. Naruse M, Takeyama Y, Tanabe A, Hiroshige J, Naruse K, Yoshimoto $\mathrm{T}$, et al. Atrial and brain natriuretic peptides in cardiovascular diseases. Hypertension 1994; 23 (Suppl 1):1231-4.

21. Yoshibayashi M, Saito Y, Nakao K. Brain natriuretic peptide versus atrial natriuretic peptide - physiological and pathophysiological significance in children and adults: a review. Eur J Endocrinol 1996; 135:265-8.

22. Clerico A, Del Ry S, Maffei S, Prontera C, Emdin M, Giannessi D. Circulating levels of cardiac natriuretic hormones in healthy adult subjects: Effects of aging and sex. Clin Chem Lab Med 2002; 40:371-7.

23. Luchner A, Brockel U, Muscholl M, Hense HW, Doring A, Riegger GAJ, et al. Gender-specific differences of cardiac remodeling in subjects with left ventricular dysfunction: a population-based study. Cardiovasc Res 2002; 53:720-7.

24. Josephson RA, Fannin S, Rinaldi J. Physiology of the aging heart. In: Chesler E, editor. Clinical cardiology in the elderly, 2nd ed. Armonk (N.Y.): Futura Publishing Company, Inc., 1999:51-77.

25. Clerico A, Del Ry S, Giannessi D. Measurement of natriuretic cardiac hormones (ANP, BNP, and related peptides) in clinical practice: the need for a new generation of immunoassay methods. Clin Chem 2000; 46:1529-34.

26. Cowie MR, Struthers AD, Wood DA, Coats AJ, Thompson SG, Poole-Wilson PA, et al. Value of natriuretic peptides in assessment of patients with possible new heart failure in primary care. Lancet 1997; 350:1349-53.

27. Schocken DD, Arrieta MI, Leaverton PE, Ross EA. Prevalence and mortality rate of congetsive heart failure in the United States. J Am Coll Cardiol 1992; 20:301-6.

28. Ho KK, Pinsky JL, Kannel WB, Levy D. The epidemiology of heart failure: the Framingham Study. J Am Coll Cardiol 1993; 22(SupplA):6a-13a.

29. McDonagh TA, Morrison CE, Lawrence A, Ford I, TunstallPedoe H, McMurray JJ, et al. Symptomatic and asymptomatic left-centricular systolic dysfunction in an urban population. Lancet 1997; 350:829-33.

30. Clinical Quality Improvement Network Investigators. Mortality risk and patterns of practisce in 4606 acute care patients with congestive heart failure. The relative impor- 
tance of age, sex, and medical therapy. Arch Intern Med 1996; 156:1669-73.

31. Adams KF Jr, Dunlap SH, Sueta CA, Clarke SW, Patterson $\mathrm{JH}$, Blauwet $\mathrm{MB}$, et al. Relation between gender, etiology and survival in patients with symptomatic heart failure. $J$ Am Coll Cardiol 1996; 28:1781-8.

32. Adams KF Jr, Sueta CA, Gheorghiade M, O'Connor CM, Schwartz TA, Koch GG, et al. Gender differences in survival in advanced heart failure. Insight from the FIRST study. Circulation 1999; 99:1816-21.

33. Philbin EF, DiSalvo TG. Influence of race and gender on care process, resource use, and hospital-based outcomes in congestive heart failure. Am J Cardiol 1998; 82:76-81.

34. Maffei S, Del Ry S, Prontera C, Clerico A. Increase in circulating levels of cardiac natriuretic peptides after hormone replacement therapy in postmenopausal women. Clin Sci 2001; 101:447-53.

35. Clerico A, lervasi G, Del Chicca MG, Maffei S, Berti S, Sabatino $L$, et al. Analytical performance and clinical usefulness of a commercially available IRMA kit for the measurement of atrial natriuretic peptide in patients with heart failure. Clin Chem 1996; 42:1627-33.

36. Weinberg EO, Thienelt CD, Katz SE, Bartunek J, Tajima M,
Rohrbach S, Douglas PS, et al. Gender differences in molecular remodelling in pressure overload hypertrophy. J Am Coll Cardiol 1999; 34:264-73.

37. Tamura T, Said S, Gerdes AM. Gender-related differences in myocyte remodelling in progression to heart failure. Hypertension 1999; 33: 676-80.

38. Wang TJ, Larson MG, Levy D, Leip EP, Benjamin EJ, Wilson PW, et al. Impact of age and sex on plasma natriuretic peptide levels in healthy adults. Am J Cardiol 2002; 90 254-8.

39. Redfield MM, Rodeheffer RJ, Jacobsen SJ, Mahoney DW, Bailey KR, Burnett JC Jr. Plasma brain natriuretic peptide concentration: impact of age and gender. J Am Coll Cardiol $2002 ; 40: 976-82$.

Received 11 December 2002, revised 17 February 2003, accepted 21 February 2003

Corresponding author: Aldo Clerico, MD, Laboratory of Cardiovascular Endocrinology, CNR Institute of Clinical Physiology, Via Trieste 41, 56126 Pisa, Italy Phone + 39-050-3152682/+39-0585-493569, Fax: +39-0585-493601, E-mail: clerico@ ifc.cnr.it 